\title{
Response of SS Multipurpose Liquid Fertilizer to Growth and Production of Petsai Plants (Brassica chinensis L.)
}

\author{
Sofyan Samad ${ }^{1, *}$, Shubzan A. Mahmud ${ }^{1}$, Hasbullah $^{2}$, Farida Maricar ${ }^{3}$ \\ ${ }^{1}$ Department Agrotechnology, Faculty of Agriculture, Khairun University, North Maluku, Indonesia \\ ${ }^{2}$ Department Agriculture Technology, Faculty of Agriculture, Khairun University, North Maluku, Indonesia \\ ${ }^{3}$ English Programme, Faculty of Cultural Science, Khairun University, North Maluku, Indonesia \\ *Corresponding author. Email: sofyan.samad1970@gmail.com
}

\begin{abstract}
Chinese cabbage plants were ones of the horticultural plants that have high economic value and support for national food security. The public demand for Chinese cabbage was increasing to meet market needs; this research needs to be done. The aim was to determine the effect of multi-use of SS organic liquid fertilizer on growth and yield of Chinese cabbage plants. The benefits of this research can actually provide information to farmers, and also provide the use of multipurpose SS liquid organic fertilizers while providing an overview of the application of eco-friendly organic farming concepts. This study used a randomized block design of multipurpose SS organic fertilizer consisting of: (A1) Multipurpose liquid organic fertilizer SS 15 cc/liter water/3 Polybag; (A2) Multi-purpose liquid organic fertilizer SS $20 \mathrm{cc} /$ liter water/3 Polybag, (A3) Multipurpose SS $25 \mathrm{cc} /$ liter water / 3 polybag liquid of organic fertilizer. There were treatments repeated 3 times until there were found 9 treatment units. The result of the research shown about effect of SS multipurposeliquid fertilizer that parameters affect and resultedin plant height $31.12 \mathrm{~cm}$, leaf area $20.2 \mathrm{~cm}$, leaf number 21 strands, plant weight $617.67 \mathrm{~g}$ and the longest roots of Chinese cabbage plant is $205 \mathrm{~cm}$.
\end{abstract}

Keywords: SS multipurpose liquid fertilizer, Chinese cabbage production

\section{INTRODUCTION}

Chinese cabbage or white mustard (Brassica chinensis L) is one of the horticultural plants that have high economic value and supports for national food security [1]. Pets are cultivated in the highlands and lowlands [2]. Chinese cabbage is popular among people because it has the best taste, and every $100 \mathrm{~g}$ of fresh Chinese cabbage contains $2.3 \mathrm{~g}$ of protein, $4.0 \mathrm{~g}$ of carbohydrates, $0.3 \mathrm{~g}$ of fat, 220 $\mathrm{mg}$ of Ca, $38 \mathrm{mg}$ of P, $2.9 \mathrm{mg} \mathrm{Fe}, 1,940 \mathrm{mg}$ of vitamin A, $0,09 \mathrm{mg}$ of vitamin B and $102 \mathrm{mg}$ of vitamin C [3].

The people's demand for Chinese cabbage is increasing, so to meet market needs, it is necessary to increase production by means of an organic agriculture system, since North Maluku in general for the development of Chinese cabbage is still minimally cultivated and especially in Ternate City. This requires knowledge about Chinese cabbage cultivation so that the success of agricultural production is in accordance with the implementation of the cultivation.

Production of Chinese cabbage in Indonesia reaches 9.91 tons / ha [4]. While the production of Chinese cabbage in the city of Ternate, reached 1.11 tons and harvested area of 114 ha[5]. The increase in Chinese cabbage production is generally inseparable from the environmental aspects of the land and climate to the condition of the growth of the cabbage. That's why the goal of agricultural technology is needed as an increase in the quality of Chinese cabbage production. The decreasing of soil quality occurs due to the use of chemical fertilizers by farmers. This is due to the application of the concept of agriculture that has come out of the concept of organic farming to pursue the target of abundance of agricultural production.

The solution to increasingChinese cabbage production is by using environmentally friendly organic fertilizers to produce higher quality white cabbage production. Basically, using organic fertilizer can restore poor soil to better. In addition, ecologically and economically, using organic fertilizer to fulfill nutrients availability in the soil. One of the liquid organic fertilizers used in this study is SS multipurpose liquid organic fertilizer, it is not harmful to human health but can increase food plant production, horticulture, livestock, and fish ponds. Furthermore, it can improve quality and quantity, and then accelerating the harvest period and increased resistance (immunity) of the plant's body and avoid pests and diseases.

The composition of the multipurpose SS organic liquid content was N 0.33\%, P2O50.17\%, K2O0.29\%, Organic C. $4.47 \%$, Protein $35.63 \%$, Carbohydrates $33.10 \%$, Fat $0.63 \%$, pH $7.1 \%$, Fe111 ppm, Mn4 ppm, Cu2 ppm, Zn9 ppm, B0.0 ppm, Humic acid 0.8 ppm, Vulcanic Acid 2, 17 ppm, Auxin, Giberelin, and Cytokinin (Anomous, 2017). To increase the production of white mustard plants, a 
study was conducted on " Influence of the provision of multi-purpose SS organic liquid fertilizer on the growth and production of Chinese cabbage plants[6] .

Based on the description of the background above, the problem of this research can be formulated as follows: How is the effect of multipurpose SS liquid organic fertilizer on the growth and yield of Chinese cabbage plants? Therefore, the aim of the study was to determine the effect of multipurpose SS organic liquid fertilizer on growth and yield of Chinese cabbage plants. The benefits of research can actually provide information to farmers in general, about the benefits of using multi-purpose SS organic liquid fertilizer while providing an overview of the application of eco-friendly organic farming concepts.

\section{RESEARCH METHODS}

This research was carried out in the Village of Gambesi, South Ternate City with an altitude of 5 meters above sea level (asl) which lasted for 5 months from May to September 2018. The tools used in this study are machete, hoe, meter, ruler, sacks, polybags, and the materials used in this study are Chinese cabbage, SS multipurpose liquid organic fertilizer, microorganisms (MO) and water.

Regarding the design, this study used a randomized block design (RAK) of multipurpose SS organic fertilizer consisting of: (A1) 15 cc fertilizer / water / 3 Polybag, (A2) $20 \mathrm{cc}$ fertilizer / water / 3 Polybag, (A3) $25 \mathrm{cc}$ fertilizer/ water / 3 polybag liquid organic fertilizer. So, there were 3 treatments can be obtained and repeated 3 times, so that there were 9 treatment units with the RAK model [7].

The implementation stagesof this study were divided into several stages of activities described as follows: (1) The planting media used consisted of soil and then the soil was put into polybags, (2) Seedlings of Chinese cabbage in containers before being transferred to polybags. Chinese cabbage seeds were sown for 2 weeks and have 2 leaves. Watering the seedling media was done every morning and evening. After the Chinese cabbage seeds were sown for 2 weeks then transferred into a polybag that has been filled with soil.

Chinese cabbage maintenance included aspects as follows: (a) Watering was carried out every morning and evening; watering was intended to maintain the availability of groundwater so that mustard plants were not drought, (b) Embedding was done if there were plants that grew unhealthy or dead plants, (c) Weeding was done to reduce competition between Chinese cabbage and weeds that grew around plants, and Chinese cabbage harvest could be harvested after crop was formed at the age of the plant reaches 60 DAT. Chinese cabbage could be harvested after the plant reaches 60 DAT. Observation parameters are plant height $(\mathrm{cm})$, leaf area $(\mathrm{cm})$, leaves number (strands), and fresh plant weight ( $\mathrm{g}$ ).

Data analysis techniques in this study using analysis of variance (ANOVA) and LeastDifference Test (BNT)with a level $(\alpha 0.05)$.

\section{RESULTS AND DISCUSSION}

\section{a. Results}

Variety analysis showed that the effect of giving multipurpose SS organic liquid fertilizer had a very significant effect on the observation variables of plant height, leaf area, the number of leaves and weight of Chinese cabbage at age 38 DAT. The average data of the effect of the effect of multipurpose SS organic liquid fertilizer on the observed variables of plant height, leaf area, the number of leaves and weight of Chinese cabbage at the age of 38 HST can be presented in Table 1.

Table 1. Data on the average effect of the influence of multipurpose SS organic liquid fertilizer on the observed variables of plant height, leaf area, number of leaves and weight of Chinese cabbage at age 38 HST

\begin{tabular}{|c|c|c|c|c|}
\hline \multirow[b]{2}{*}{ Perlakuan } & \multicolumn{4}{|c|}{38 DAT treatment } \\
\hline & Plant height $(\mathrm{cm})$ & $\begin{array}{c}\text { Leaf area } \\
(\mathrm{cm})\end{array}$ & $\begin{array}{c}\text { Number of leaves } \\
\text { (strands) }\end{array}$ & $\begin{array}{c}\text { Weight krop fresh } \\
\text { cabbage }(\mathrm{g})\end{array}$ \\
\hline $\begin{array}{c}15 \mathrm{cc} / \text { liter of water } \\
/ 3 \text { polybag }\left(A_{1}\right)\end{array}$ & $27.24^{\mathrm{a}}$ & $16.6^{\mathrm{a}}$ & $18^{\mathrm{a}}$ & $340.22^{a}$ \\
\hline $\begin{array}{c}20 \mathrm{cc} / \text { liter of water } \\
/ 3 \text { polybag }\left(\mathrm{A}_{2}\right)\end{array}$ & $30.54^{b}$ & $19.4^{b}$ & $21^{\mathrm{b}}$ & $514.22^{b}$ \\
\hline $\begin{array}{c}25 \mathrm{cc} / \text { liter of water } \\
/ 3 \text { polybag }\left(\mathrm{A}_{3}\right)\end{array}$ & $31.12^{b}$ & $20.2^{b}$ & $21^{b}$ & $617.67^{\mathrm{c}}$ \\
\hline BNT 0.05 & 2.1 & 1.82 & 2.66 & 111.01 \\
\hline
\end{tabular}

Remarks: The average number followed by the same letter is not significantly different at the level of the BNT 0.05

Based on the results of the variance analysis, it showed that the effect of giving multipurpose SS organic liquid fertilizer on treatment $\mathrm{A} 3$ produced the highest plant 31.12 $\mathrm{cm}$ and was not significantly different from A2 treatment but was significantly different from the A1 treatment at age 38 HST. Whereas in the broad component of leaf treatment $\mathrm{A} 3$ produced the leaves of the widest plant 20.2 $\mathrm{cm}$ and not significantly different from the A2 treatment but it was significantly different from treatment $\mathrm{A} 1$, and the number of leaves showed that treatment $\mathrm{A} 3$ produced the highest number of plants 21 A2 but was significantly different from treatment A1. Likewise, the parameter observations of the weight of the Chinese cabbage crop showed that treatment A3 visually yielded the heaviest 
crop weight of $617.67 \mathrm{~g}$ and was significantly different from treatment $\mathrm{A} 2$ and significantly different from treatment A1 (Table 1).
Root length $(\mathrm{cm})$. Variety analysis showed that the treatment of 25 ccfertilizers/ water / 3 polybag had a significant effect on the average root length. The average root length is shown in Figure 1.

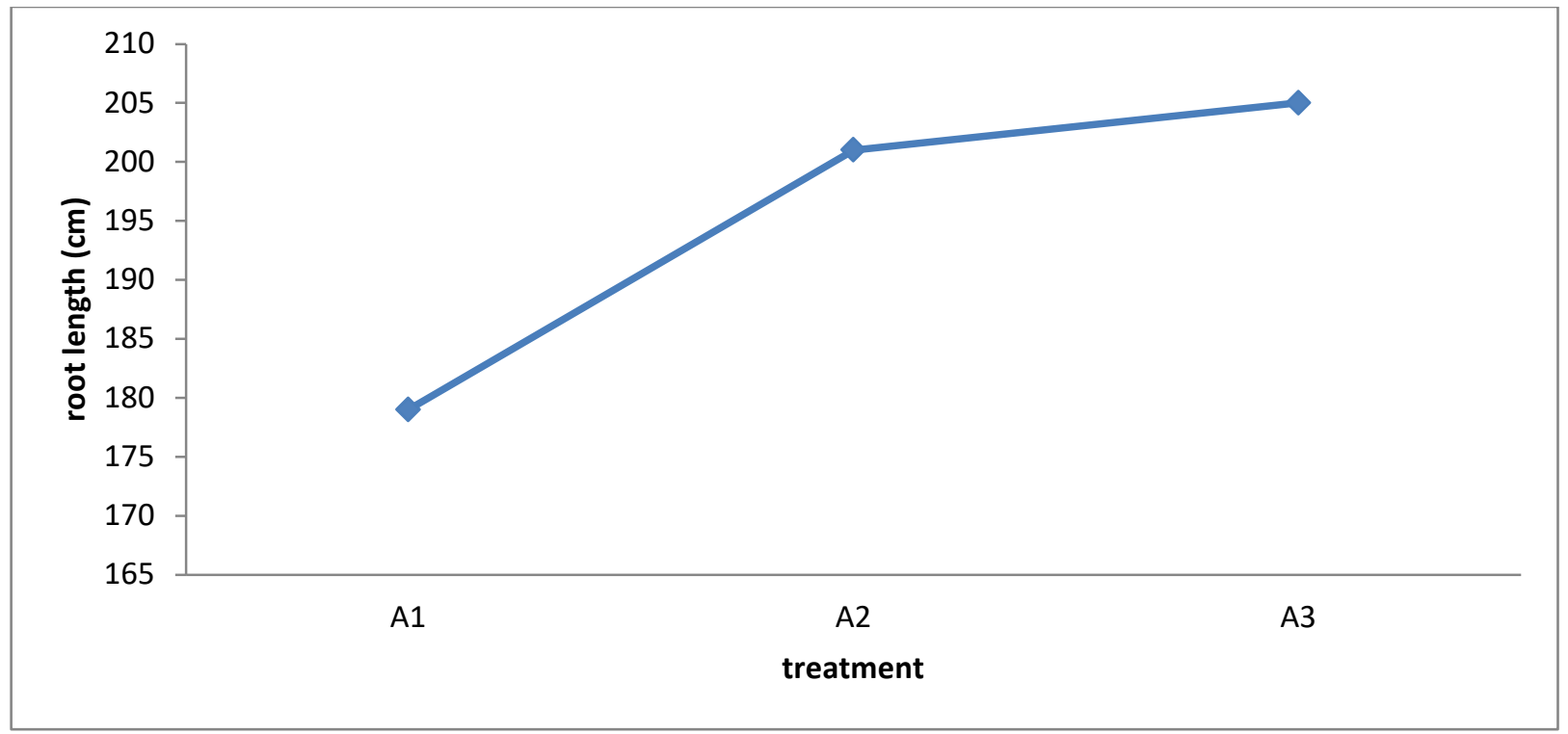

Figure 1. Long histogram of the roots of Chinese cabbage at the time of panan

Figure 1 shows that a root length of $205 \mathrm{~cm}$ was obtained in treatment A3. This shows that carrying $\mathrm{N}$ elements in liquid organic fertilizer can meet the needs of Chinese cabbage plants

\section{b. Discussion}

The effect of giving multipurpose SS organic liquid fertilizer had a significant effect on plant height, leaf area, number of leaves, and weight of fresh Chinese cabbage or white mustard seeds.

Plant height $(\mathbf{c m})$. Based on the results of theanalysis of variance at the age of 38 HST, it was shown that the effect of giving multipurpose SS organic liquid fertilizer at a dose of $25 \mathrm{cc} /$ liter of water / 3 polybags produced the highest crop $31.12 \mathrm{~cm}$ (Table 1) compared to other treatments. It is presumed that the higher the dose of fertilizer given the more plant growth. In line with the statement of [8]. that the higher the dose of fertilizer is, the more nutrients are supplied for plant growth. The whole elements absorbed by plants influence each other, so that the multi-purpose SS organic liquid fertilizer provided can support the high growth of Chinese cabbage plants. In addition, according to[9] the plant growth develops rapidly when essential nutrients are available in sufficient quantities. According to [10] plant height is one component of plant growth that is easily seen. Besides changes in temperature, and high rainfall can hamper the process of growth and production [11].

Leaf area $(\mathbf{c m})$. The analysis of variance showed that the effect of giving multiple SS multipurpose organic fertilizers with a dose of $25 \mathrm{cc} /$ liter of water / 3 polybes produced leaves of the widest plant $20.2 \mathrm{~cm}$ (Table 1). This study supports the opinion (Wahyudi, 2010) that organic fertilizers containing nitrogen and nitrogen function to increase vegetative growth, so that the leaves of the plant become wider, greener and more quality. While the opinion of [12] that the amount of biomass of a plant shows the process of plant growth and development goes well. Another opinion also [13] that the need for organic fertilizers and soil is strongly influenced by climate, physiology and plant morphology as well as temperature and solar radiation factors affecting the rate of photosynthesis. Leaves are the main organ to absorb sunlight and photosynthesis to produce a number of organic chemical compounds that are very important in supporting plant growth. The more leaves that are formed, the more opportunities for plants to absorb sunlight to photosynthesis. It is suspected that the administration of organic matter has shown the response of plants to nutrients given through the formation of good leaf quality. Number of leaves (strands). The variance analysis showed that the effect of giving SS multipurpose liquid organic fertilizer at a dose of $25 \mathrm{cc}$ liter of water at the age of $38 \mathrm{HST}$ the leaves of the 21 st cabbage plant (strands) (Table 1). It is assumed that the increase in dosage for each treatment and the value of sufficient and balanced nutrient content needed by plants to produce. In line with the opinion [14] that an increase in N nutrients in the soil to increase vegetative growth. Leaves are one of the vegetative organs that play a role in the process of photosynthesis. This photosynthesis will be used to arrange plants and as a food storage organ in plants. The increase in the number of leaves is a morphological pattern 
and increase in size, the number of cells that occur at the growth point which is the metabolic activity and physiology that takes place in cells. Sunlight takes place to support the occurrence of photosynthesis and the results will be translated into the formation of plant growth that occurs at the point of growing plants [15]. The growth rate or increase in the number of leaves depends on how large the ability of plants to absorb nutrients in the soil and how much nutrient adequacy in the soil to support the growth of Chinese cabbage plants for decay leaves absorb sunlight and form flowers. According to [14] that nutrient $\mathrm{N}$ supports leaf growth in the vegetative vase.

Fresh weight of Chinese cabbage crop (g). The variance analysis showed that the effect of giving SS multipurpose liquid organic fertilizer at a dose of $25 \mathrm{cc} /$ liter of water visually resulted in the weight of the Chinese cabbage crop $617.67 \mathrm{~g}$ (Table 1). This is presumed because the provision of multi-purpose SS organic liquid fertilizer has responded well to the fresh weight of Chinese cabbage, the formation of crop is highly dependent on how much leaf formation and plant height increase, the more leaves are formed and the higher the plant weight. Furthermore, according to [16] nutrients in the soil are sufficient for plant growth. Correspondingly, water is accelerating the process of plant growth and the environment. While according to [17] that nutrients are used by plants in the process of assimilation and physiology

Root length (cm). The variation analysis showed that the treatment of liquid organic fertilizer $25 \mathrm{cc} /$ liter of water / 3 polybag produced the longest root $205 \mathrm{~cm}$. This shows that liquid organic fertilizer can meet the needs of Chinese cabbage plants to carry out cell extension in the root area.

\section{CONCLUSION}

The effect of giving SS multipurpose liquid organic fertilizer at a dose of $25 \mathrm{cc} /$ liter / 3 polybag significantly affected all parameters and produced plant height of 31.12 $\mathrm{cm}$, leaf area of $20.2 \mathrm{~cm}$, leaf number of 21 strands, fresh weight of Chinese cabbage plant $617.67 \mathrm{~g}$ and Chinese cabbage root length $205 \mathrm{~cm}$.

\section{REFERENCES}

[1] O. Chunhachart et al 2014. The growth of Brassica chinensis in heavy-metal-contaminated sewage sludge compost from Hong Kong.

[2] Rukmana, R. 2007. Bertanam Petsai dan Sawi. Kanisius, Yogyakarta.

[3] Haryanto, Eko. 2007.SawidanSelada. Jakarta :PenebarSwadaya. 112ha

[4] Badan Pusat Statistikdan Direktorat Jenderal, 2016. .Produktivitas Sayuran di Indonesia.

[5] BPS Maluku Utara, 2015.Luas PanenProduksidan Rata-rata Produksi Sayur-sayuran Menurut Jenis Tanaman Tahun 2015.

[6] Anonim, 20017.Pupuk Cair Multi guna SS.
[7] Hanafiah, 2010. Rancangan Percobaan teori dan aplikasi. Edisi ketiga. Rajawali Pers.

[8] Pranata, A.S. 2004. Pupuk Organik Cair Aplikasi dan Manfaatnya. Agromedia Pustaka. Jakarta.

[9] Ridwan.2001. Pengaruh Pupuk Organik Dengan Pupuk Hayati Untuk Meningkatkan Efisiensi Penggunaan Hara Pertumbuhan dan Produksi Tanaman Cabai, Tesis.IPB. Bogor.

[10] Hakim, N.,Mala, Y ., dan Agustian. 2009. Pembuatan dan Pemanfaatan Pupuk Organik Titonia Plus Dalam Penerapan Metode SRI pada Sawah Bukaan Baru. Laporan HasilPenelitian. Kerjasama Universitas Andalas dengan Sekretariat Badan Penelitian dan Pengembangan Pertanian.

[11] Rimuza, Radzka, and Lenartowicz T., 2015. Effect of weather conditions on early potato yieds In eats central Poland. Communications in Biometry and Crop Science. Vol. 10, No.2,2015, PP. 65- 72.

[12] Fahrudin, Fuat. 2009. Budidaya Caisim(Brassica junceaL.) Menggunakan Ekstrak Teh dan Pupuk Kascing.Surakarta. Universitas Sebelas Maret.

[13] Hasibuan, Malayu S.P., 2011. Manajemen Sumber Daya Manusia. Bumi Aksara, Jakarta.

[14] Martin,E.C., D.C. Slack., K.A. Tanksley, and B. Basso. 2006. Effects of fresh composted dairy mamure aplicatons on alfalfa yield and the environment in Arizona. Agron. J. 98:80-94.

[15] Suciantini, 2015. Relationship between climate (rainfaal) and crop production in Pacitan. PROS SEM NAS MASY BIODIV INDON Volume1, Nomor 2, April 2015 Halaman: 358- 365. Diakses 19 November 2019.

[16] Sutedjo M. 2010. Pupukdan Cara Pemupukan. Rineka Cipta. Jakarta.

[17] Taiz, L., E. Zeiger. 2002. Plant Physiology. Third Edition. Sinauer Associate Inc. Publisher Sunderland. Massachusetts. 667 p. Diakses 14 November 2019. 